\title{
PUBLISITAS
}

Journal of Social Sciences and Politics

Vol. 7 No. 2 April 2020

p-ISSN : 2252-4150

e-ISSN : 2716-3474

Tersedia online di http://ejurnal.stisipolcandradimuka.ac.id/index.php/JurnalPublisitas/

\section{Analisis Kualitas Pelayanan Kesehatan Ibu Hamil Di Pusat Kesehatan Masyarakat Swasti Saba Kota Lubuk Linggau}

\author{
Any Mulyati ${ }^{1}$, Trecy Austin ${ }^{2}$ \\ ${ }^{1}$ Program Studi Administrasi Publik, Pascasarjana Universitas Sriwijaya Palembang \\ ${ }^{2}$ Program Studi Ilmu Administrasi Negara, STISIPOL Candradimuka Palembang \\ Email: anie_apt14@yahoo.com ${ }^{1}$, trecy.austin@gmail.com ${ }^{2}$
}

\begin{abstract}
ABSTRAK
Penelitian bertujuan mengukur kualitas pelayanan dalam lima dimensi kualitas pelayanan (Servqual) yaitu dimensi fisik, kehandalan, daya tanggap, jaminan dan empati. Penelitian ini deskriptif kuantitatif dengan sampel sebanyak 65 ibu hamil pengguna layanan. Instrumen penelitian menggunakan kuesioner. Hasil analisis kesenjangan menunjukkan nilai kesenjangan dimensi servqual bernilai negatif $(<0)$ baik itu di loket pendaftaran, poli pelayanan dan apotek, nilai ini menunjukkan bahwa kualitas pelayanan kesehatan ibu hamil di Puskesmas Swasti Saba belum baik. Faktor-faktor yang mempengaruhi kualitas pelayanan kesehatan ibu hamil di loket pendaftaran Puskesmas Swasti Saba adalah ketersediaan prasarana/sarana di Puskesmas, dengan tersedianya ruang tunggu yang nyaman, proses pendaftaran menggunakan komputerisasi, tersedianya gambaran alur pelayanan yang dipasang di bagian depan loket dan SDM yang dalam hal ini terkait dengan kehadiran, komitmen dan daya tanggap dari petugas puskesmas untuk memberikan pelayanan. Pada poli pelayanan yaitu ketersediaan prasarana/sarana pelayanan di Poli KIA, diantaranya ketersediaan peralatan pemeriksaan lengkap dan modern, ruang tunggu poli nyaman, tersedia SOP pelayanan di ruang poli, dan ruang pelayanan kesehatan ibu yang nyaman dan tertutup, kompetensi dan daya tanggap bidan di poli KIA dalam memberikan pelayanan kepada ibu hamil. Faktor yang mempengaruhi pelayanan Apotek yaitu ketersediaan prasarana/sarana pelayanan di ruang tunggu apotek yang nyaman, selain itu ketersediaan obat untuk ibu hamil yang lengkap dengan disertai pengemasan yang baik dan aturan pakai yang jelas dan SDM petugas apotek dalam hal ini terkait keberadaan, kompetensi dan daya tanggap petugas apotek dalam memberikan pelayanan kefarmasian.
\end{abstract}

Kata kunci : Kualitas Pelayanan, Ibu Hamil, SERVQUAL

\section{ABSTRACT}

The study aims to measure service quality in five dimensions of service quality (Servqual), namely physical dimensions, reliability, responsiveness, assurance and empathy. This research is descriptive quantitative with a sample of 65 pregnant women who use services. The research instrument used a questionnaire. Service clinic and pharmacy, this value indicates that the quality of health services for pregnant women at Swasti Saba Puskesmas is not good. Factors that affect the quality of pregnant women's health services at the registration counter of the Swasti Saba Puskesmas are the availability of infrastructure / facilities at the Puskesmas, the availability of a comfortable waiting room, the registration process is computerized, the availability of an overview of the service flow installed at the front of the counter and human 
resources. In service poly, namely the availability of infrastructure / service facilities at the KIA Poly, including the availability of complete and modern examination equipment, a comfortable poly waiting room, available operational standards for services in the poly room, and a comfortable and closed maternal health service room, the competence and responsiveness of midwives in poly $\mathrm{MCH}$ in providing services to pregnant women. Factors that affect Pharmacy services are the availability of infrastructure / service facilities in a comfortable pharmacy waiting room, besides the availability of drugs for pregnant women that are complete with good packaging and clear rules of use and the human resources of pharmacy staff in this case related to existence, competence and power responsive pharmacy officers in providing pharmaceutical services.

Keywords: Quality of Service, Pregnant Women, SERVQUAL

\section{PENDAHULUAN}

Menurut Peraturan Menteri Kesehatan Nomor 75 Tahun 2014 tentang Pusat Kesehatan Masyarakat menyatakan bahwa setiap puskesmas harus menyelenggarakan upaya kesehatan masyarakat untuk mendukung pencapaian Standar Pelayanan Minimal bidang kesehatan.

Kenyataannya, pelayanan kesehatan ibu hamil di Kota Lubuk Linggau terindikasi kurang berkualitas, khususnya di Puskesmas Swasti Saba. Hal ini bisa dilihat dari:

1. Masih tingginya Angka Kematian Ibu (AKI) di Kota Lubuklinggau yaitu sebesar 6/3149 kelahiran hidup

2. Masih adanya ibu hamil yang tidak memeriksakan dan mendapatkan pelayanan kesehatan selama masa kehamilannya di Kota Lubuklinggau, yang terlihat dari cakupan K1 yang hanya sebesar $66,05 \%$ dan cakupan k4 62,14\%.

Kedua alasan tersebutlah yang mendorong peneliti tertarik untuk mengkaji dan mengangkat permasalahan kualitas pelayanan kesehatan ibu hamil. Dua hal yang menjadi indikator terhadap kualitas pelayanan kesehatan dan derajat kesehatan masyarakat di suatu wilayah adalah Angka Kematian Ibu atau Maternal Mortalilaty Rate (MMR) dan Angka Kematian Bayi (AKB) atau Infant Mortality Rate (IMR).

Puskesmas Swasti Saba saat ini memiliki ruang pelayanan kesehatan ibu hamil. Peralatan kesehatan yang dimiliki oleh Puskesmas Swasti Saba masih kurang lengkap, dari 36 item alat kesehatan yang harus ada di ruang pelayanan kesehatan ibu hanya tersedia 15 item alat kesehatan atau hanya sebesar $41,67 \%$ saja yang dimiliki oleh Puskesmas Swasti Saba. Kekurangan sarana dan prasarana ini juga akan mempengaruhi kualitas pelayanan kesehatan ibu hamil di Puskesmas Swasti Saba.

Buruknya kualitas pelayanan kesehatan antenatal, persalinan, dan pasca persalinan merupakan hambatan utama untuk menurunkan kematian ibu. Berdasarkan kenyataan empiris tersebut, maka penelitian ini bermaksud untuk mengetahui kondisi kualitas pelayanan kesehatan ibu hamil yang diberikan karena hanya masyarakat atau publik 
yang bisa memberikan penilaian sebenarnya atas pelayanan yang mereka peroleh. Dalam upaya pemberian pelayanan kesehatan kepada masyarakat khususnya ibu hamil, perlu diketahui pasti kualitas pelayanan yang diberikan di Puskesmas Swasti. Penelitian ini mencoba menganalisis kualitas pelayanan kesehatan ibu hamil yang diterima pelanggan dalam hal ini masyarakat yang memanfaatkan jasa Puskesmas Swasti Saba Kota Lubuklinggau.

Berdasarkan pokok-pokok permasalahan yang diuraikan sebelumnya, maka dalam penelitian ini ada dua rumusan masalah, yaitu: [1] Bagaimana kualitas pelayanan kesehatan ibu hamil di Puskesmas Swasti Saba di Kota Lubuklinggau, [2] Faktor-faktor apakah yang mempengaruhi kualitas pelayanan kesehatan ibu hamil di Puskesmas Swasti Saba di Kota Lubuklinggau.

Hasil penelitian ini diharapkan dapat memberikan manfaat dan kontribusi ilmiah dalam pengembangan Ilmu administrasi dan kebijakan publik di bidang pelayanan kesehatan. Memberi gambaran yang jelas tentang kualitas pelayanan kesehatan yang diberikan oleh Puskesmas Swasti Saba di Kota Lubuklinggau, Memberi masukan bagi instansi (Dinas Kesehatan Kota Lubuklinggau, Puskesmas Swasti Saba) dalam pengambilan kebijakan untuk perbaikan pelayanan puskesmas di lingkungan Pemerintah Kota Lubuklinggau, dan dapat membantu dan memberikan informasi bagi pihak yang ingin meneliti lebih jauh dalam hal analisis kebijakan publik khususnya dalam hal peningkatan kualitas pelayanan kesehatan

\section{TINJAUAN PUSTAKA}

Pengertian kualitas lebih luas dikatakan oleh Daviddow dan Uttal (1989:19) dalam Hardiyansyah (2011) yaitu merupakan usaha apa saja yang digunakan untuk mempertinggi kepuasan pelanggan (whatever enhances customer satisfaction). Sedangkan menurut Sinambela dkk (2014:6) kualitas adalah segala sesuatu yang mampu memenuhi keinginan atau kebutuhan pelanggan (meeting the needs of customers).

Kualitas pelayanan adalah pelayanan yang diberikan oleh penerima layanan sesuai dengan standar pelayanan yang telah dibakukan sebagai pedoman dalam pemberian layanan. Standar pelayanan adalah ukuran yang telah ditentukan sebagai suatu pembakuan pelayanan yang baik (Dwiyanto, 2003).

Zeithaml, Parasuraman., dan Berry (1990:175) lebih lanjut menyatakan dimensi-dimensi disederhanakan menjadi 5 kategori, yaitu:

1. Tangibility, meliputi fasilitas fisik, perlengkapan, dan material yang digunakan perusahaan, serta penampilan karyawan.

2. Reliability, yaitu kemampuan perusahaan untuk memberikan pelayanan yang dijanjikan dengan tepat waktu dan memuaskan.

3. Responsiveness, yaitu kemampuan para staf untuk membantu para pelanggan dan memberikan pelayanan dengan tanggap.

4. Assurance, mencakup kemampuan, kesopanan dan sifat dapat dipercaya 
yang dimiliki Para staf, bebas dari bahaya, resiko atau keragu-raguan.

5. Emphaty, mencakup kemudahan dalam melakukan hubungan komunikasi yang baik dan memahami kebutuhan para pelanggan.

\section{Kerangka Pikir Penelitian}

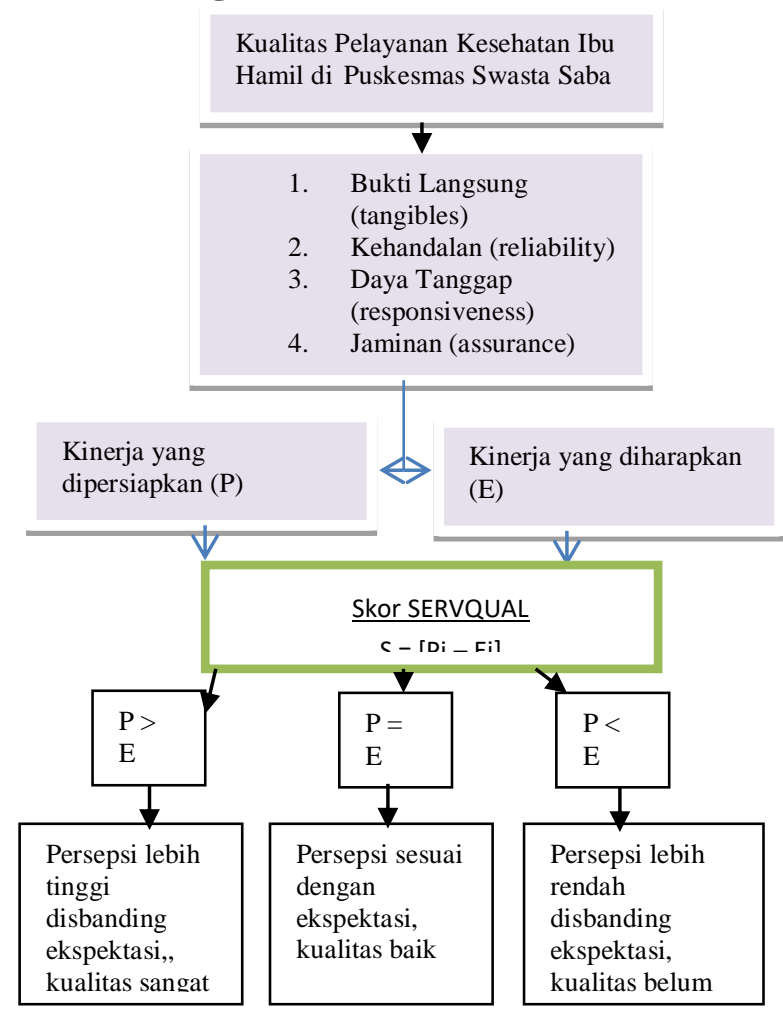

Gambar 1. Kerangka Pemikiran

\section{Hipotesis Penelitian}

Berdasarkan uraian pada kerangka pemikiran, dirumuskanlah hipotesis penelitian ini, yaitu diduga kualitas pelayanan kesehatan ibu hamil di Puskesmas Swasti Saba Kota Lubuklinggau belum baik yang sesuai dengan teori yang menyatakan bahwa kualitas belum baik jika nilai persepsi lebih besar dari nilai harapan.

\section{METODE PENELITIAN}

Penelitian ini menggunakan desain deskriptif kuantitatif. Penelitian deskriptif kuantitatif dimaksudkan untuk menggambarkan, menjelaskan atau meringkaskan berbagai kondisi, situasi fenomena atau berbagai variabel penelitian menurut kejadian sebagaimana adanya yang dapat dipotret, diwawancarai, diobservasi serta yang dapat diungkapkan melalui bahan-bahan dokumenter.

Instrumen penelitian yang digunakan adalah kuesioner. Kuesioner digunakan untuk mendapatkan informasi yang lebih luas dalam subyek penelitian. Penyajian data melalui tabel, diagram, perhitungan rata-rata dan persentase akan dijelaskan secara deskriptif untuk menjelaskan kualitas pelayanan kesehatan ibu hamil menurut masyarakat pengguna layanan Puskesmas Swasti Saba.

\section{Defini Konsep}

Didefinisikan konsep-konsep sebagai berikut:

1. Pelayanan kesehatan ibu hamil adalah setiap upaya yang diselenggarakan sendiri atau secara bersama-sama dalam suatu organisasi untuk memelihara dan meningkatkan kesehatan ibu hamil sehingga mampu melahirkan generasi yang sehat dan berkualitas serta mengurangi angka kematian ibu.

2. Tangibles (bukti langsung), yakni fasilitas fisik dan peralatan serta penampilan personil yang terdapat dalam Puskesmas Swasti Saba Kota 
Lubuklinggau.

3. Reliability (keandalan), yakni kemampuan Puskesmas Swasti Saba Kota Lubuklinggau dalam memberikan pelayanan yang dijanjikan dengan baik dan akurat.

4. Responsiveness (ketanggapan), yakni kesanggupan Puskesmas Swasti Saba Kota Lubuklinggau dalam membantu pelanggan dan melakukan pelayanan yang cepat.

5. Assurance (jaminan), yakni keramahan (kesopanan) petugas Puskesmas Swasti Saba Kota Lubuklinggau dan kemampuannya dalam memberikan keyakinan kepada pengguna layanan.

6. Emphaty (empati), yakni kemampuan Puskesmas Swasti Saba Kota Lubuklinggau dalam memberikan perhatian dan layanan individu kepada pengguna layanan.

7. Pelanggan adalah individu yang menggunakan jasa pelayanan publik berupa pelayanan kesehatan di Puskesmas Swasti Saba Kota Lubuklinggau.

8. Ekspektasi (harapan) adalah suatu keadaan yang menjadi impian individu ketika individu tersebut datang ke Puskesmas Swasti Saba Kota Lubuklinggau.

9. Persepsi adalah suatu keadaan apa yang dirasakan/dialami individu ketika individu tersebut menerima layanan dari Puskesmas Swasti Saba Kota Lubuklinggau.

\section{Definisi Operasional}

Variabel, dimensi, indikator, dan deskripsi yang akan ditentukan dalam analisis kualitas pelayanan kesehatan ibu hamil di Puskesmas Swasti Saba Kota Lubuklinggau selengkapnya dapat dilihat pada Tabel 1.

\section{Tabel 1. Definisi Operasional}

\begin{tabular}{|c|c|c|}
\hline Dimensi & Indikator & Deskripsi \\
\hline \multirow[t]{4}{*}{ Tangibles } & $\begin{array}{l}\text { Kelengkapan } \\
\text { Fasilitas Fisik }\end{array}$ & $\begin{array}{ll}\text { a. } & \text { Loket } \\
& \text { pendaftaran } \\
\text { b. } & \text { Ruang } \\
& \text { Pemeriksaan } \\
& \text { Kesahatan Ibu } \\
\text { c. } & \text { Ruang Persalinan } \\
\text { d. } & \text { Laboratorium } \\
\text { e. } & \text { Apotik } \\
\text { f. } & \text { WC } \\
\text { g. } & \text { Tempat Parkir }\end{array}$ \\
\hline & $\begin{array}{ll}\text { 2. } & \begin{array}{l}\text { Kelengkapan } \\
\text { peralatan } \\
\text { pelayanan }\end{array}\end{array}$ & $\begin{array}{ll}\text { a. } & \text { Tempat tidur } \\
& \text { periksa pasien } \\
\text { b. } & \text { Pendingin } \\
& \text { ruangan } \\
\text { c. } & \text { USG } \\
\text { d. } & \text { Tensimeter } \\
\text { e. } & \text { Timbangan }\end{array}$ \\
\hline & $\begin{array}{ll}\text { 3. } & \text { Penampilan } \\
& \text { Pegawau } \\
& \text { Puskesmas }\end{array}$ & $\begin{array}{ll}\text { a. } & \text { Memakai } \\
& \text { seragam } \\
\text { b. } & \text { Memakai atribut } \\
\text { lengkap }\end{array}$ \\
\hline & $\begin{array}{ll}4 . & \text { Ruang Tunggu } \\
& \text { Puskesmas }\end{array}$ & $\begin{array}{ll}\text { a. } & \text { Tempat duduk } \\
\text { b. } & \text { Bersih dan rapih }\end{array}$ \\
\hline \multirow[t]{4}{*}{ Reliability } & $\begin{array}{ll}\text { 1. } & \text { Kejelasan } \\
& \text { Prosedur } \\
& \text { Pendaftaran }\end{array}$ & $\begin{array}{ll}\text { a. } & \text { Alur Pelayanan } \\
\text { b. } & \text { Persyaratan Jelas } \\
\text { c. } & \text { Tidak berbelit- } \\
& \text { belit } \\
\text { d. } & \begin{array}{l}\text { Pelayanan sesuai } \\
\text { dengan yang }\end{array} \\
\text { dijanjikan } \\
\text { e. Mutu Kemasan } \\
\text { obat }\end{array}$ \\
\hline & 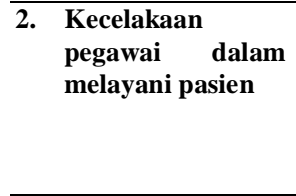 & $\begin{array}{ll}\text { a. } & \begin{array}{l}\text { Pelayanan sesuai } \\
\text { prosedur }\end{array} \\
\text { b. } & \text { Dokter/Bidan } \\
\text { memiliki } \\
\text { kemampuan } \\
\text { memeriksa pasien }\end{array}$ \\
\hline & $\begin{array}{l}\text { 3. Keberadaan dan } \\
\text { kesiapan pegawai } \\
\text { di Puskesman } \\
\text { untuk melayani }\end{array}$ & 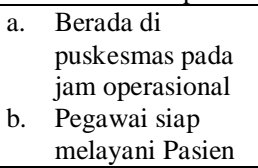 \\
\hline & $\begin{array}{l}\text { 4. Ketepatan jadwal } \\
\text { jam buka dan } \\
\text { tutup Puskesmas }\end{array}$ & $\begin{array}{ll}\text { a. } & \text { Pelayanan } \\
& \text { dimulai pukul } \\
& 08.00 \\
\text { b. } & \text { Pelayanan ditutup } \\
& \text { pukul } 14.00 \\
& \text { (senin-kamis), } \\
& 11.00 \text { (jumat) dan } \\
& 12.00 \text { (sabtu) }\end{array}$ \\
\hline \multirow[t]{2}{*}{$\begin{array}{l}\text { Responsive } \\
\text { ness }\end{array}$} & $\begin{array}{l}\text { 1. Kecepatan } \\
\text { pegawai dalam } \\
\text { memberikan } \\
\text { Pelayanan }\end{array}$ & $\begin{array}{ll}\text { a. } & \text { Tindakan dengan } \\
& \text { cepat } \\
\text { b. } & \text { Pasien tidak } \\
& \text { menunggu terlalu } \\
\text { lama }\end{array}$ \\
\hline & $\begin{array}{ll}\text { 2. } & \text { Kecepatan } \\
\text { Pegawai dalam } \\
\text { menyelesaikan } \\
\text { masalah }\end{array}$ & $\begin{array}{ll}\text { a. } & \text { Tidak menunda } \\
& \text { menyelesaikan } \\
& \text { masalah } \\
\text { b. } & \text { Menolong }\end{array}$ \\
\hline
\end{tabular}




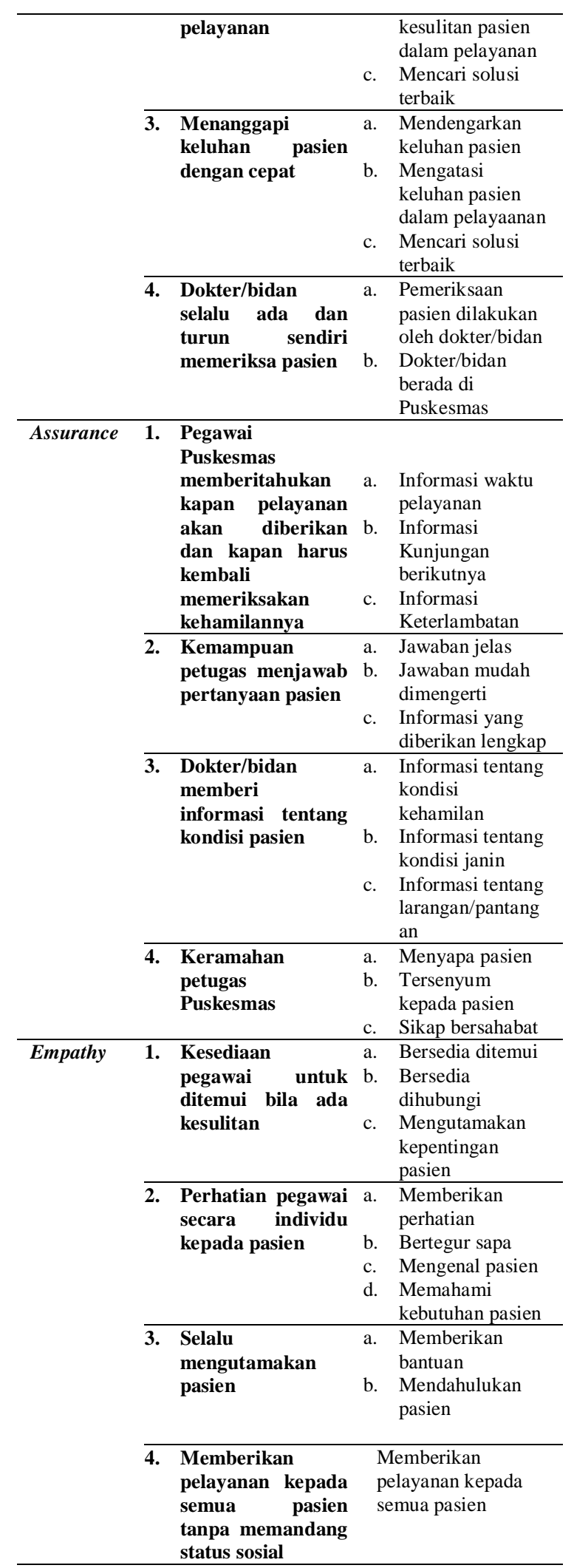

Sumber: diolah oleh Penulis

Berdasarkan perhitungan, didapat jumlah sampel sebesar 64 orang. Dalam penelitian ini penulis mengambil sampel sebanyak 65 orang. Penentuan sampel untuk menjadi responden dilakukan secara sampling insidentil yakni teknik penentuan sampel berdasarkan kebetulan, yaitu siapa saja yang secara kebetulan bertemu dengan peneliti dapat digunakan sebagai sampel bila dipandang orang yang kebetulan ditemui itu cocok sebagai sumber data sesuai dengan ketentuan penelitian (Sugiyono, 2010:67). Teknik pengumpulan data penelitian ini adalah kuesioner, dokumentasi, dan wawancara

\section{Instrumen Penelitian}

Instrumen penelitian yang digunakan adalah kuesioner (daftar pertanyaan). Penentuan nilai skor menggunakan skala likert (Riduwan, 2009:20), menyebutkan bahwa dengan skala likert maka variabel yang akan diukur dijabarkan menjadi dimensi dan dimensi dijabarkan lagi menjadi indikator - indikator yang dapat diukur. Adapun alasan menggunakan skala likert dalam penelitian ini adalah karena dalam penggunaannya, skala likert dapat dibuat dan dinterpretasikan dengan mudah dan skala likert merupakan bentuk pengukuran yang lazim dipakai.

Ada 5 alternatif jawaban untuk harapan, yaitu:

Skor 1, dikategorikan Sangat Tidak Baik/Sesuai

Skor 2, dikategorikan Tidak Baik/Sesuai

Skor 3, dikategorikan Ragu-ragu

Skor 4, dikategorikan Baik/Sesuai

Skor 5, dikategorikan Sangat Baik/Sesuai

Ada 5 alternatif jawaban untuk persepsi yaitu:

Skor 1, dikategorikan Sangat Tidak Setuju 
Skor 2, dikategorikan Tidak Setuju

Skor 3, dikategorikan Ragu-ragu

Skor 4, dikategorikan Setuju

Skor 5, dikategorikan Sangat Setuju

\section{Uji Validitas Instrumen Penelitian}

Metode yang digunakan menguji validitas instrumen dengan menghitung nilai korelasi antara data pada masingmasing pernyataan dengan skor total memakai rumus teknik korelasi product moment (Umar, 2004:83). Teknik korelasi product moment merupakan suatu analisis yang digunakan untuk mengetahui derajat hubungan dan kontribusi variabel bebas (independent) dengan variabel terikat (dependent). Teknik analisis korelasi product moment termasuk teknik statistik parametrik yang menggunakan data interval dan ratio dengan persyaratan tertentu. Berikut tabel indeks korelasi (r), dilihat di Tabel 2.

Tabel 2

Interpretasi Koefisien Korelasi Nilai $\mathbf{r}$

\begin{tabular}{cc}
\hline Interval Koefisien & Tingkat Hubungan \\
\hline $0,800-1,000$ & Sangat Tinggi \\
\hline $0,600-0.799$ & Tinggi \\
\hline $0,400-0,599$ & Cukup Tinggi \\
\hline $0,200-0,399$ & Rendah \\
\hline $0,000-0,199$ & $\begin{array}{c}\text { Sangat Rendah (tidak } \\
\text { valid) }\end{array}$ \\
\hline
\end{tabular}

Sumber: Riduwan (2010:110)

Berdasarkan tabel hasil uji validitas menunjukkan bahwa semua nilai koefisien $\mathrm{r}$ instrumen dimensi Tangibility, Reliability, Responsiveness, Assurance,

Emphaty memiliki nilai > rtabel yaitu 0,359 yang berarti instrumen dari dimensi-dimensi tersebut seluruhnya dinyatakan valid. Hal ini menunjukkan bahwa semua item yang dijadikan sebagai indikator terhadap kualitas pelayanan berdasarkan persepsi dan harapan telah sah untuk dijadikan alat ukur.

\section{Uji Reliabilitas Instrumen Penelitian}

Reliabilitas

memberikan gambaran sejauh mana suatu pengukuran dapat dipercaya, artinya sejauh mana skor hasil pengukuran terbebas dari kesalahan pengukuran. Tinggi reliabilitas secara empiris ditunjukkan oleh suatu angka yang disebut koefisien reliabilitas. Secara teoritis besarnya koefisien reliabilitas berkisar antara $0,00-1,00$.

Adapun ukuran kemantapan alpha dapat diinterpretasikan seperti Tabel 3.

Tabel 3

Interpretasi Tingkat Reliabilitas

\begin{tabular}{|c|c|c|}
\hline $\begin{array}{l}\text { Nilai } \\
\text { Cronbach }\end{array}$ & Alpha & Tingkat Reliabilitas \\
\hline 0,00 s.d 0,20 & & Kurang Reliabel \\
\hline 0,21 s.d 0,40 & & Agak Reliabel \\
\hline 0,41 s.d 0,60 & & Cukup Reliabel \\
\hline 0,61 s.d 0,80 & & Reliabel \\
\hline 0,81 s.d 1,00 & & Sangat Reliabel \\
\hline
\end{tabular}

Masih tingginya Uji Reliabilitas dalam penelitian ini menggunakan rumus keandalan alat ukur Cronbach's Alpha. Instrumen dinyatakan reliabel apabila nilai Cronbach's Alpha nya $\geq 0,61$. Berdasarkan hasil uji reliabilitas yang dilakukan pada item pernyataan persepsi dan harapan kepada 20 responden menunjukkan nilai Cronbach's Alpha $\geq$ 0,61 yang berarti bahwa pernyataan dari Dimensi Tangible (Bukti Fisik), Reability (keandalan), Responsiveness (daya tanggap), Assurance (jaminan/kepastian), Emphaty (perhatian) adalah reliabel. Oleh sebab itu semua instrumen pernyataan 
kuesioner dipakai semua untuk mengetahui kualitas pelayanan kesehatan ibu hamil di puskesmas.

Hasil Uji Reliabilitas Instrumen dari tiap-tiap dimensi yang diperoleh dari hasil pengolahan data dengan bantuan Program Statistical Package fo Social Science (SPSS). Dapat dilihat pada Tabel 4 sampai dengan Tabel 6

\begin{tabular}{|c|c|c|c|c|c|c|}
\hline \multirow[b]{3}{*}{ No } & \multicolumn{6}{|c|}{$\begin{array}{c}\text { Tabel } 4 \\
\text { Hasil Uji Reliabilitas di Loket } \\
\text { Pendaftaran } \\
\end{array}$} \\
\hline & \multirow[b]{2}{*}{ Dimensi } & \multicolumn{2}{|r|}{ Persepsi } & \multicolumn{2}{|c|}{ Harapan } & \multirow{2}{*}{ Ket. } \\
\hline & & $\mathbf{N}$ & $\begin{array}{c}\text { Cronbach's } \\
\text { Alpha }\end{array}$ & & $\begin{array}{c}\text { Cronbach's } \\
\text { Alpha }\end{array}$ & \\
\hline 1 & $\begin{array}{l}\text { Tangible } \\
\text { (Bukti Fisik) }\end{array}$ & 4 & 0,766 & 4 & 0,744 & Reliabel \\
\hline 2 & $\begin{array}{l}\text { Reliability } \\
\text { (keandalan) }\end{array}$ & 4 & 0,886 & 4 & 0,662 & Reliabel \\
\hline 3 & $\begin{array}{l}\text { Responsivene } \\
\text { ss (daya } \\
\text { tanggap) }\end{array}$ & 3 & 0,882 & 3 & 0,703 & Reliabel \\
\hline 4 & $\begin{array}{l}\text { Assurance } \\
\text { (jaminan/kep } \\
\text { astian) }\end{array}$ & 4 & 0,838 & 4 & 0,675 & Reliabel \\
\hline 5 & $\begin{array}{l}\text { Emphaty } \\
\text { (perhatian) }\end{array}$ & 4 & 0,871 & 4 & 0,876 & Reliabel \\
\hline
\end{tabular}

\section{Tabel 5}

Hasil Uji Reliabilitas di Poli KIA






\section{HASIL PENELITIAN}

Responden berdasarkan usia dikelompokkan menjadi 3 kelompok yaitu kelompok usia < 19 tahun, kelompok usia 19 - 35 tahun dan kelompok usia > 35 tahun. Usia responden yang berkunjung ke Puskesmas Swasti Saba di Kota Lubuklinggau. Hasil penelitian menunjukkan bahwa sebagian besar responden yang berkunjung ke Puskesmas Swasti Saba di Kota Lubuklinggau berusia 19 - 35 tahun yaitu sebanyak 49 orang $(75,40 \%)$, hal ini disebabkan karena usia tersebut merupakan usia produktif yang aman untuk hamil dan melahirkan (tidak beresiko tinggi). Hasil penelitian juga menunjukkan masih terdapat ibu hamil yang berusia 19 tahun yaitu sebanyak 8 orang $(12,30 \%)$ dan juga masih terdapat ibu hamil di usia $>35$ tahun sebanyak 8 orang $(12,30 \%)$. Usia tersebut merupakan usia resiko tinggi untuk kehamilan.

Hasil penelitian menunjukkan bahwa sebagian besar responden yang berkunjung ke Puskesmas Swasti Saba Kota Lubuklinggau berpendidikan Sekolah Menengah Atas sebesar 56,92\%. Hal ini sesuai dengan data statistik Kecamatan Lubuklinggau Timur II bahwa sebagian besar penduduk di wilayah ini berpendidikan SMA, dan hanya $0,44 \%$ saja penduduk wilayah Lubuklinggau Timur II yang menempuh pendidikan sarjana.

Responden yang paling banyak adalah ibu rumah tangga atau ibu hamil yang tidak bekerja (45 responden atau $66,15 \%)$ dan responden yang paling sedikit adalah ibu hamil yang bekerja sebagai PNS yaitu sebesar (4 responden atau sebesar 6,15\%). Sementara untuk responden yang bekerja pada swasta ada sebanyak 8 orang, ibu hamil yang berwiraswata atau berdagang sebanyak 3 orang dan ibu hamil yang bertani atau berkebun sebanyak 5 orang. Hal ini sesuai dengan data statistik bahwa mayoritas penduduk di wilayah Kecamatan Lubuklinggau Timur II berprofesi sebagai buruh dan pedagang sedangkan sisanya berprofesi sebagai PNS, pegawai swasta, dosen dan wiraswasta.

Secara keseluruhan kualitas pelayanan kesehatan ibu di Puskesmas Swasti Saba masih belum baik dilihat dari nilai gap antara persepsi dan harapan yang bernilai negatif, baik itu di loket pendaftaran, poli KIA maupun di apotek. Hasil ini menunjukkan bahwa Puskesmas Swasti Saba belum dapat memenuhi harapan ibu hamil. Nilai gap terbesar terletak pada pelayanan di loket pendaftaran yaitu sebesar -1,07 dengan nilai persepsi 3,27 dan nilai harapan sebesar 4,34. Kemudian pelayanan di apotek dengan nilai gap sebesar $-1,06$ dengan nilai persepsi 3,29 dan nilai harapan sebesar 4,35. Yang terakhir adalah pelayanan pada poli kesehatan ibu dengan nilai gap sebesar -0,95 dimana nilai persepsi sebesar 3,44 dan harapan sebesar 4,39. Nilai gap rata-rata per dimensi pada masing-masing tempat pelayanan dapat dilihat pada Tabel 7 . 
Tabel 7

Kualitas Pelayanan Puskesmas Swasti

Saba

\begin{tabular}{|c|c|c|c|}
\hline $\begin{array}{l}\text { Dimensi Kualitas } \\
\text { No } \\
\quad \text { Pelayanan }\end{array}$ & $\begin{array}{l}\text { Rata- } \\
\text { Rata }\end{array}$ & $\begin{array}{l}\text { Rata- } \\
\text { rata }\end{array}$ & $\begin{array}{l}\text { Gap } \\
\text { (P-H) }\end{array}$ \\
\hline $\begin{array}{c}\text { Loket } \\
\text { Pendaftaran }\end{array}$ & & & \\
\hline $\begin{aligned} & \text { Dimenis } \\
& 1 \text { Tangibles } \\
&\end{aligned}$ & 3,26 & 4,36 & $-1,11$ \\
\hline $\begin{aligned} & \text { Dimensi } \\
& 2 \text { Reliability } \\
&\end{aligned}$ & 3,07 & 4,37 & $-1,30$ \\
\hline $\begin{aligned} & \text { Dimensi } \\
& 3 \text { Responsiveness } \\
&\end{aligned}$ & 3,24 & 4,32 & $-1,08$ \\
\hline $\begin{array}{c}\text { Dimensi } \\
4 \text { Assurance } \\
\end{array}$ & 3,56 & 4,30 & $-0,75$ \\
\hline $\begin{array}{c}5 \text { Dimensi Emphaty } \\
\begin{array}{c}\text { Skor Rata- } \\
\text { rata }\end{array} \\
\end{array}$ & $\begin{array}{r}3,23 \\
\mathbf{3 , 2 7} \\
\end{array}$ & $\begin{array}{r}4,33 \\
\mathbf{4 , 3 4} \\
\end{array}$ & $\begin{array}{l}-1,10 \\
\mathbf{- 1 , 0 7} \\
\end{array}$ \\
\hline Poli KIA & & & \\
\hline $\begin{aligned} & \text { Dimenis } \\
& 1 \text { Tangibles } \\
&\end{aligned}$ & 3,41 & 4,45 & $-1,04$ \\
\hline $\begin{aligned} & \text { Dimensi } \\
& 2 \text { Reliability } \\
&\end{aligned}$ & 3,31 & 4,49 & $-1,17$ \\
\hline $\begin{array}{ll} & \text { Dimensi } \\
3 \text { Responsiveness } \\
\end{array}$ & 3,29 & 4,40 & $-1,12$ \\
\hline $\begin{array}{c}\text { Dimensi } \\
4 \text { Assurance } \\
\end{array}$ & 3,60 & 4,32 & $-0,72$ \\
\hline 5 Dimensi Emphaty & 3,57 & 4,32 & $-0,76$ \\
\hline $\begin{array}{c}\text { Skor Rata- } \\
\text { rata }\end{array}$ & 3,44 & 4,39 & $-0,95$ \\
\hline Apotek & & & \\
\hline $\begin{aligned} & \text { Dimenis } \\
& 1 \text { Tangibles } \\
&\end{aligned}$ & 3,04 & 4,36 & $-1,32$ \\
\hline $\begin{aligned} & \text { Dimensi } \\
& 2 \text { Reliability } \\
&\end{aligned}$ & 3,25 & 4,40 & $-1,15$ \\
\hline $\begin{array}{ll} & \text { Dimensi } \\
3 & \text { Responsiveness } \\
\end{array}$ & 3,25 & 4,36 & $-1,11$ \\
\hline $\begin{aligned} & \text { Dimensi } \\
& 4 \text { Assurance } \\
&\end{aligned}$ & 3,39 & 4,39 & $-1,00$ \\
\hline 5 Dimensi Emphaty & 3,52 & 4,22 & $-0,70$ \\
\hline $\begin{array}{c}\text { Skor Rata- } \\
\text { rata }\end{array}$ & 3,29 & 4,35 & $-1,06$ \\
\hline
\end{tabular}

\section{PEMBAHASAN}

Hasil analisa kesenjangan antara persepsi dan ekspektasi baik pada loket pendaftaran, poli pelayanan dan apotek diperoleh nilai negatif dari seluruh dimensi, hal ini menunjukkan bahwa kualitas pelayanan kesehatan ibu hamil di Puskesmas Swasti Saba Kota Lubuklinggau belum baik. Dari kelima dimensi kualitas pelayanan pada loket pendaftaran dan poli pelayanan kesehatan ibu nilai kesenjangan terbesar terletak pada pada dimensi kehandalan, sementara pada pelayanan apotek kesenjangan terbesar terletak pada dimensi bukti fisik.

Indikator yang menjadi prioritas untuk mendapatkan penanganan pada loket pendaftaran Puskesmas Swasti Saba antara lain ruang tunggu loket pendaftaran, keberadaan dan kesiapan pegawai untuk memberikan layanan, ketepatan jadwal buka dan tutup loket. Dan terakhir adalah menanggapi keluhan pasien dengan cepat. Pada poli pelayanan kesehatan ibu yaitu ruang tunggu poli kesehatan ibu, keberadaan dan kesiapan pegawai untuk memberikan pelayanan serta ketepatan jadwal buka dan tutup poli kesehatan ibu. Pada pelayanan apotek yaitu pada ruang tunggu apotek, keberadaan dan kesiapan petugas apotek, ketepatan waktu buka dan tutup apotek di puskesmas serta kecepatan pegawai dalam menyelesaikan permasalahan.

Berdasarkan hasil analisis diatas maka ditemukan beberapa hal yang dianggap mempengaruhi kualitas pelayanan kesehatan ibu hamil di Puskesmas Swasti Saba Kota Lubuklinggau, sebagai berikut: 


\section{Kurangnya ketersediaan Sarana dan Prasarana}

Ketersediaan sarana dan prasarana sebagai penunjang dalam kegiatan Pelayanan kesehatan ibu hamil di Puskesmas Swasti Saba sangat penting, tanpa adanya sarana dan prasarana suatu program tidak dapat berjalan dengan baik. Dalam penelitian ini ketersediaan sarana dan prasarana di Puskesmas Swasti Saba masih kurang terutama untuk ketersediaan peralatan kesehatan. Alat kesehatan merupakan instrument, apparatus, mesin, implant yang tidak mengandung obat, digunakan untuk mendiagnosa penyakit merawat orang sakit, menyembuhkan dan memulihkan serta membentuk struktur dan memperbaiki jaringan tubuh (Kemenkes,2014). Salah satu komponen penting di sebuah puskesmas adalah ketersedian alat kesehatan yang memadai. Inilah yang nantinya akan mensukseskan kegiatan pelayanan kesehatan dan juga kesehatan masyarakat di lingkungannya. Selain alat kesehatan, media penyuluhan seperti alat peraga untuk kegiatan promotif merupakan hal yang sangat diperlukan dalam upaya pelayanan kesehatan ibu hamil di puskesmas.

Loket pendaftaran tidak tersedia papan informasi yang akan memudahkan pasien dalam melakukan pendaftaran dan poli pelayanan kesehatan ibu telah memiliki ruang pelayanan kesehatan ibu yang tertutup dan nyaman serta memiliki papan penunjuk ruangan. Sementara pada apotek fasilitas fisik di apotek kurang lengkap, hal ini dikarenakan belum tersedianya loket penerimaan dan penyerahan obat, sehingga penerimaan dan penyerahan obat hanya dilakukan di satu meja saja.

\section{Kurangnya jumlah tenaga kesehatan}

Kurangnya tenaga kesehatan dalam hal ini bidan juga menjadi penghambat dalam pelaksanaan pelayanan kesehatan ibu hamil di Puskesmas Swasti Saba. Tenaga kesehatan merupakan hal yang penting dalam pelaksanaan suatu pelayanan kesehatan, tenaga kesehatan yang dimaksud antara lain bidan, perawat, dan dokter. Puskesmas Swasti Saba hanya memiliki 5 bidan, namun hanya 2 orang bidan yang bertugas di poli pelayanan kesehatan ibu. Berdasarkan Peraturan Menteri Kesehatan RI nomor 33 tahun 2015 tentang Pedoman Penyusunan Kebutuhan Sumber Daya Kesehatan menyebutkan bahwa rasio bidan adalah 100 per 100.000 penduduk, sementara untuk Puskesmas Swasti Saba rasio bidan adalah 5 per 14.115 penduduk atau 35 per 100.000 penduduk. Jadi untuk SDM pelayanan kesehatan ibu hamil di Puskesmas Swasti Saba masih kurang

\section{Kurangnya disiplin pegawai puskesmas}

Puskesmas Swasti Saba baru mulai memberikan pelayanan pada pukul 09.00dan sudah ditutup pada pukul 12.00 WIB yang seharusnya ditutup pada pukul 14.00 WIB, sehingga jika ada ibu hamil yang datang diatas jam tersebut tidak mendapatkan pelayanan. Artinya ibu hamil merasakan puskesmas belum dapat memenuhi harapan ibu hamil terhadap pemenuhan janji secara tepat waktu. Ketepatan waktu sangat erat kaitannya 
dengan kehandalan pelayanan yang diberikan yang akan mempengaruhi penilaian ibu hamil terhadap kualitas pelayanan.

\section{Pelayanan kesehatan ibu hamil belum sesuai dengan standar pelayanan ibu hamil}

Pelayanan kesehatan ibu hamil di Puskesmas Swasti Saba Kota Lubuklinggau belum sesuai dengan standar pelayanan yang terdiri atas: a). Timbang berat badan dan ukur tinggi badan dengan alat timbangan dan mikrotois. b)Ukur tekanan darah dengan alat tensimeter; c) Nilai status gizi (ukur lingkar lengan atas) dengan meteran; d) Ukur tinggi fundus uteri; e) Tentukan presentasi janin dan denyut jantung janin dengan alat stetoskop; f) Skrining status imunisasi tetanus dan berikan imunisasi tetanus toksoid bila diperlukan dengan alat form skrining; g) Pemberian tablet zat besi minimal 90 tablet selama masa kehamilan; h)Test laboratorium (rutin dan khusus); i) Temu wicara (konseling). Pelayanan yang diberikan pada ibu hamil di Puskesmas Swasti Saba hanya berupa pemeriksaan pengukuran tekanan darah, penimbangan pada ibu hamil, serta pengukuran lingkar lengan atas saja dimana seharusnya dilakukan pemeriksaan penunjang yang antara lain adalah pemeriksaan $\mathrm{Hb}$ dan vaksinasi. Puskesmas Swasti Saba hanya melakukan pemeriksaan $\mathrm{Hb}$ pada ibu hamil yang memiliki keluhan saja.

\section{KESIMPULAN DAN SARAN}

\section{Kesimpulan}

Berdasarkan hasil penelitian dengan menggunakan model SERVQUAL yang mencakup perhitungan perbedaan diantara nilai yang diberikan oleh ibu hamil untuk setiap pasang pernyataan berkaitan dengan harapan dan persepsi, menunjukkan bahwa pelayanan kesehatan ibu hamil di Puskesmas Swasti Saba Kota Lubuklinggau belum berkualitas, hal ini bisa dilihat dari gap antara persepsi dan harapan yang bernilai negatif yang berarti bahwa pelayanan belum baik, baik itu di loket pendaftaran, poli pelayanan kesehatan ibu dan apotek. Pada loket pendaftaran, nilai gap dimensi tangibless $-1,11$, dimensi reliability $-1,30$, dimensi responsiveness $-1,08$, dimensi assurance $-0,75$ dan dimensi emphaty -1,10. Pada poli pelayanan kesehatan ibu, nilai gap dimensi tangibless -1,04, dimensi reliability -1,17, dimensi responsiveness 1,12, dimensi assurance $-0,72$ dan dimensi emphaty -0,76. Dan pada pelayanan apotek, dimensi tangibless 1,32 , dimensi reliability $-1,15$, dimensi responsiveness $-1,11$, dimensi assurance $-1,00$ dan dimensi emphaty $-0,70$.

Faktor-faktor yang mempengaruhi kualitas pelayanan pada masing-masing tempat pelayanan yaitu:

1. Loket pendaftaran: ketersediaan prasarana/sarana pelayanan di Puskesmas, diantaranya adalah dengan tersedianya ruang tunggu yang nyaman, proses pendaftaran dengan menggunakan komputerisasi, tersedianya gambaran alur pelayanan yang dipasang dibagian depan loket. Sumber Daya Manusia yang dalam hal ini terkait dengan kehadiran, komitmen dan daya tanggap dari petugas puskesmas untuk memberikan pelayanan juga mempengaruhi 
penilaian pasien terhadap kualitas pelayanan.

2. Poli KIA:Ketersediaan prasarana/ sarana pelayanan di Poli KIA, diantaranya ketersediaan peralatan pemeriksaan kesehatan ibu hamil yang lengkap dan modern, ruang tunggu poli yang nyaman, tersedia SOP pelayanan di ruang poli, dan ruang pelayanan kesehatan ibu yang nyaman dan tertutup. SDM Puskesmas dalam hal ini trekait keberadaan, kompetensi dan daya tanggap bidan di poli KIA dalam memberikan pelayanan kepada ibu hamil dan membantu ibu hamil pada saat pemeriksaan kehamilan.

3. Apotek : ketersediaan prasarana/sarana pelayanan di apotek, dalam hal ini loket pelayanan apotek yang nyaman bagi pasien untuk melakukan konsultasi obat, ruang tunggu apotek yang nyaman, selain itu ketersediaan obat untuk ibu hamil yang lengkap dengan disertai pengemasan yang baik dan aturan pakai yang jelas. SDM petugas apotek dalam hal ini terkait keberadaan, kompetensi dan daya tanggap petugas apotek dalam memberikan pelayanan kefarmasian mulai dari saat menerima resep sampai dengan menyerahkan obat.

\section{Saran}

1. Meningkatkan kualitas pelayanan yang diharapkan oleh masyarakat khususnya ibu hamil pada semua dimensi perlu adanya komitmen yang kuat dari pihak puskesmas dan pengambil kebijakan dalam hal ini Dinas Kesehatan dan Pemerintah Kota Lubuklinggau untuk melakukan upaya khusus dalam meningkatkan kualitas pelayanan kesehatan ibu hamil. Dalam hal ini dengan kebijakan Puskesmas BLUD sehingga diharapkan dapat meningkatkan kualitas pelayanan.

2. Perlu melengkapi fasilitas dan prasarana puskesmas seperti yang diharapkan oleh masyarakat, baik itu kelengkapan alat-alat pelayanan kesehatan dengan pengadaan alat-alat yang sesuai standar pelayanan dan bahan pendukung lainnya serta peningkatan fasilitas puskesmas lainnya seperti menata kembali ruang tunggu dan ruang pelayanan sehingga nyaman dan bersih serta tersedianya WC yang bersih untuk pengunjung puskesmas.

3. Meningkatkan kualitas Sumber Daya Manusia Puskesmas melalui pendidikan dan pelatihan aparatur tenaga kesehatan yang berbasis pada kebutuhan puskesmas salah satunya melalui pelatihan pelayanan prima bagi seluruh pegawai puskesmas, sehingga diharapkan dapat meningkatkan kualitas pelayanan kesehatan melalui tenaga kesehatan yang berkualitas.

4. Pelayanan pada loket pendaftaran sebaiknya sudah menggunakan sistem komputerisasi, ataupun mengadakan pembakuan prosedur urutan pelayanan mulai dari pendaftaran pasien sampai dengan pengobatan dan pemberian obat, serta menampilkan prosedur urutan tersebut di gedung bagian depan sehingga bisa terlihat dengan mudah oleh pasien yang datang. 


\section{Saran Akademis}

Mengembangkan studi mengenai kebijakan publik, khususnya yang berkaitan dengan kualitas pelayanan kesehatan, maka perlu dilakukan penelitian-penelitian lanjutan baik dengan metode kuantitatif ataupun kualitatif sehingga penelitian selanjutnya diharapkan dapat mengukur dan menggambarkan kualitas pelayanan kesehatan di Kota Lubuklinggau dengan lebih mendalam dan mampu meningkatkan kualitas pelayanan.

\section{DAFTAR PUSTAKA}

[1] Peraturan Menteri Kesehatan Republik Indonesia Nomor 75 Tahun 2014 Tentang Pusat Kesehatan Masyarakat.

[2] Statistik Daerah Lubuklinggau Timur II Tahun 2017, Badan Pusat Statistik Kota Lubuklinggau

[3] Hardiyansyah. 2011. Kualitas Pelayanan Publik: Konsep, Dimensi, Indikator dan Implementasinya. Yogyakarta: Penerbit Gaya Media

[4] Sinambela, Lijan, dkk. 2006. Reformasi Pelayanan Publik: Teori, Kebijakan, Implementasi, Jakarta: Bumi Aksara

[5] Dwiyanto, Agus, dkk. 2003. Reformasi Tata Pemerintahan dan Otonomi Daerah. Yogyakarta: PSKKUGM.

[6] Tjiptono, Fandy dan Chandra, G. 2011. Service, Quality \& Satisfaction. Edisi 3. Yogyakarta: Penerbit Andi

[7] Tjiptono, Fandy. 2011. Service Management - Mewujudkan
Pelayanan Prima. Yogyakarta: Penerbit Andi.

[8] Riduwan. 2010. Metode dan Teknik Menyusun Tesis. Bandung: Penerbit Alfabeta

[9] Keputusan Menteri Kesehatan Republik Indonesia Nomor 828/Menkes/SK/IX/2008 Tahun 2003 tentang Pedoman Umum Penyelenggaraan Pelayanan Publik.

[10] Peraturan Menteru Kesehatan RI Nomor 33 Tahun 2015 tentang Pedoman Penyusunan Kebutuhan Sumber Daya Kesehatan. 